\title{
Different doses of supplemental vitamin D maintain interleukin-5 without altering skeletal muscle strength: a randomized, double-blind, placebo-controlled study in vitamin $\mathrm{D}$ sufficient adults
}

Tyler Barker ${ }^{1,8^{*}}$, Thomas B Martins ${ }^{2}$, Harry R Hill ${ }^{2,3}$, Carl R Kjeldsberg ${ }^{2,3}$, Vanessa T Henriksen ${ }^{1}$, Brian M Dixon ${ }^{4}$, Erik D Schneider ${ }^{4}$, Adam Dern ${ }^{4}$ and Lindell K Weaver ${ }^{5,6,7}$

\begin{abstract}
Background: Supplemental vitamin D modulates inflammatory cytokines and skeletal muscle function, but results are inconsistent. It is unknown if these inconsistencies are dependent on the supplemental dose of vitamin D. Therefore, the purpose of this study was to identify the influence of different doses of supplemental vitamin D on inflammatory cytokines and muscular strength in young adults.

Methods: Men $(n=15)$ and women $(n=15)$ received a daily placebo or vitamin D supplement (200 or 4000 IU) for 28-d during the winter. Serum 25-hydroxyvitamin D $(25(\mathrm{OH}) \mathrm{D})$, cytokine concentrations and muscular (leg) strength measurements were performed prior to and during supplementation. Statistical significance of data were assessed with a two-way (time, treatment) analysis of variance (ANOVA) with repeated measures, followed by a Tukey's Honestly Significant Difference to test multiple pairwise comparisons.

Results: Upon enrollment, $63 \%$ of the subjects were vitamin D sufficient (serum $25(\mathrm{OH}) \mathrm{D} \geq 30 \mathrm{ng} / \mathrm{ml}$ ). Serum $25(\mathrm{OH}) \mathrm{D}$ and interleukin $(\mathrm{IL})-5$ decreased $(P<0.05)$ across time in the placebo group. Supplemental vitamin $\mathrm{D}$ at 200 IU maintained serum 25(OH)D concentrations and increased IL-5 $(P<0.05)$. Supplemental vitamin D at 4000 IU increased $(P<0.05)$ serum 25(OH)D without altering IL-5 concentrations. Although serum 25(OH)D concentrations correlated $(P<0.05)$ with muscle strength, muscle strength was not changed by supplemental vitamin $D$.

Conclusion: In young adults who were vitamin $\mathrm{D}$ sufficient prior to supplementation, we conclude that a low-daily dose of supplemental vitamin D prevents serum $25(\mathrm{OH}) \mathrm{D}$ and IL-5 concentration decreases, and that muscular strength does not parallel the $25(\mathrm{OH}) \mathrm{D}$ increase induced by a high-daily dose of supplemental vitamin $\mathrm{D}$. Considering that IL-5 protects against viruses and bacterial infections, these findings could have a broad physiological importance regarding the ability of vitamin D sufficiency to mediate the immune systems protection against infection.
\end{abstract}

Keywords: Vitamin D, Interleukin-5, Skeletal muscle function

\footnotetext{
* Correspondence: tyler.barker@imail.org

${ }^{1}$ The Orthopedic Specialty Hospital, Murray, UT, 84107, USA

Full list of author information is available at the end of the article
} 


\section{Introduction}

Vitamin D status is influenced by a variety of factors, including but not limited to geographical latitude, season and supplement use. Living in extreme northern and southern climates and the winter season result in low vitamin D levels [1,2], while supplemental vitamin D increases serum 25-hydroxyvitamin D $(25(\mathrm{OH}) \mathrm{D})$ in a dosedependent fashion [3-5]. Serum 25(OH)D is the best indicator of vitamin D status [6], but 1 $\alpha, 25$-dihydroxyvitamin $\mathrm{D}_{3}(1,25(\mathrm{OH}) \mathrm{D})$ is the active form of vitamin $\mathrm{D}$ that regulates biological functions. In kidney and immune cells, $1 \alpha$-hydroxylase ( $1 \alpha$-OHase) converts $25(\mathrm{OH}) \mathrm{D}$ to 1,25 $(\mathrm{OH}) \mathrm{D}$. This enzymatic conversion is limited by substrate availability since $1 \alpha$-OHase operates below its $K_{\mathrm{m}}$. Thus, an adequate circulating $25(\mathrm{OH}) \mathrm{D}$ concentration is necessary to maintain substrate availability for the enzymatic conversion of vitamin $\mathrm{D}$ to its active form.

Low serum 25(OH)D concentrations result in skeletal muscle weakness $[7,8]$, and in pathophysiological and physiological conditions, correlate with muscular strength or physical performance [9-14]. These findings suggest that increasing serum $25(\mathrm{OH}) \mathrm{D}$ concentration improves muscular strength. Consistent with this deductive reasoning, supplemental vitamin D reversed vitamin D deficiencyinduced weakness in elderly $[10,15]$ and in patients with diverse diseases or illnesses [16-18]. Although we previously demonstrated that serum $25(\mathrm{OH}) \mathrm{D}$ concentration is influential on muscle strength recovery following ligamentous injury and surgery in active adults [19], it is unknown if supplemental vitamin D increases muscular strength simultaneous with serum $25(\mathrm{OH}) \mathrm{D}$ concentrations in young, reportedly active and healthy adults.

Vitamin D regulates inflammatory cytokines, which orchestrate host defenses by the immune system. Interferon (IFN)- $\gamma$ is a cytokine that regulates $\mathrm{T}$ helper $1\left(\mathrm{~T}_{\mathrm{H} 1}\right)$ type cells and pathways [20-22], and in immune cells, is regulated by vitamin D [23-25]. Interleukin (IL)-5 and IL10 regulate $\mathrm{T}_{\mathrm{H} 2}$-type cell pathways [26-30] and are modulated by vitamin D [31-34]. Despite previous reports identifying the influence of vitamin $\mathrm{D}$ on cytokine production in vitro, evidence illustrating concurrent alterations in serum $25(\mathrm{OH}) \mathrm{D}$ and cytokine concentrations in humans is more ambiguous. For example, in healthy-adults during the winter, low serum $25(\mathrm{OH}) \mathrm{D}$ concentrations corresponded with increased IFN- $\gamma$ and IL-10 production [35], while supplemental vitamin D (cholecalciferol) increased IL-10 in congestive heart failure patients [36] but was ineffective at modulating IFN- $\gamma$, IL-5 or IL-10 in overweight or obese subjects [37]. Currently, it is unknown if supplemental vitamin $\mathrm{D}$ modulates inflammatory cytokines concomitantly with serum $25(\mathrm{OH}) \mathrm{D}$ concentrations in young, healthy adults during the winter.

To date, one study has examined the influence of different doses of supplemental vitamin D on serum 25
$(\mathrm{OH}) \mathrm{D}$ simultaneously with circulating cytokines in healthy adults during the winter, and the range of supplemental vitamin $\mathrm{D}$ (cholecalciferol) doses were narrow (i.e., 200, 400 and $600 \mathrm{IU} / \mathrm{d}$ ) [38]. Additionally, it is unknown whether short-term and different doses of supplemental vitamin $\mathrm{D}$ modulate muscular strength similarly despite divergent serum $25(\mathrm{OH}) \mathrm{D}$ concentration responses. Therefore, the purpose of this study was to identify the influence of low and high doses of supplemental vitamin D on serum $25(\mathrm{OH}) \mathrm{D}$, inflammatory cytokines and muscular strength in young adults during the winter. We hypothesized that a 'low' daily dose of supplemental vitamin D maintains serum $25(\mathrm{OH}) \mathrm{D}$ concentration, and that a 'high' daily dose is necessary to modulate circulating cytokines and muscular strength in young adults during the winter. To test this hypothesis, subjects were provided a daily placebo supplement or supplemental vitamin D at different doses (200 or 4000 IU) in a randomized, double-blind experimental design. Supplements were taken for 28-d during the winter, and serum $25(\mathrm{OH}) \mathrm{D}$, cytokine and muscular strength measurements were performed prior to and during the supplemental intervention in young, reportedly active and healthy adults. We demonstrate in young adults who were vitamin D sufficient prior to supplementation that a low-daily dose of supplemental vitamin D prevents serum $25(\mathrm{OH}) \mathrm{D}$ and IL-5 concentration decreases, and that muscular strength does not parallel the $25(\mathrm{OH}) \mathrm{D}$ increase induced by a high-daily dose of supplemental vitamin D.

\section{Methods}

The Institutional Review Board at Intermountain Healthcare (Murray, UT, USA) approved this study. Subjects were informed of the experimental protocol and procedures and provided both written and verbal consent prior to participation. Recreationally active (minimum of 30 minutes of continuous exercise at least 3 time per week for 1 year prior to enrollment), non-smoking males and females between the ages of 18 and 45 years of age were recruited to participate in this study. Subjects were excluded from participation if they experienced a lowerextremity injury or injuries during the year prior to enrollment. Subjects were also excluded from participation if they were taking a daily dietary-supplement during the previous year, planning on increasing or decreasing the amount of time spent in the sun or tanning bed, or traveling south of $37^{\circ} \mathrm{N}$ latitude during enrollment. Subjects were asked to refrain from using any other supplements during study participation. Data was collected during two successive winters. First, between December 1, 2009 and April 26, 2010, and second, between December 1, 2010 and March 15, 2011 in Salt Lake City, UT USA $\left(40^{\circ} \mathrm{N}\right.$ latitude). We chose to collect data during the 
winter because that is when vitamin D levels are at their nadir. This occurs because the solar angle during the winter is inadequate to stimulate cutaneous vitamin D synthesis from sun (ultraviolet B radiation) exposure.

\section{Study design and protocol}

This study consisted of a randomized, double-blind, placebo-controlled experimental design. Subjects were randomly assigned to one of three groups: vitamin D (cholecalciferol) supplementation at: (1) 200 or (2) 4000 IU, or (3) a matching-placebo. Supplements were taken daily for 28-d. Supplements were permutated into random blocks of six. Subjects were asked to refrain from using aspirin, ibuprofen, naproxen sodium, and acetaminophen throughout the duration of the study.

It should be noted, that upon study initiation, $200 \mathrm{IU} / \mathrm{d}$ of vitamin $\mathrm{D}$ was the recommended-adequate intake and $4000 \mathrm{IU} / \mathrm{d}$ was double the upper limit for the targeted population. Currently, $200 \mathrm{IU} / \mathrm{d}$ is lower than the current recommended dietary allowance and $4000 \mathrm{IU}$ is the upper limit for the studied population. These recommendations are provided by the Institute of Medicine for the United States and Canada [39]. Although recommendations changed during the course of this study, the experimental design (randomized, double-blind, placebo-controlled) and the examination of two different doses of supplemental vitamin $\mathrm{D}$ are strengths of this investigation.

\section{Analytical procedures}

Each subject provided five fasting blood draws: (1) prior to (Pre), and (2) 7-, (3) 14-, (4) 21 - and (5) 28-d after supplementation. Subjects were asked to refrain from physical activity 72-h prior to each blood draw to ensure that prior activity did not confound serum $25(\mathrm{OH}) \mathrm{D}$ and cytokine concentration results. Fasting blood draw samples were obtained from the antecubital vein into one $4.0 \mathrm{ml}$ purpletop Becton Dickinson (BD) Vacuatainer tube (K2 EDTA $7.2 \mathrm{mg}$ ), one $4.5 \mathrm{ml}$ light green-top BD Vacutainer tube (PST Gel and Lithium Heparin, 83 units), and one $6.0 \mathrm{ml}$ red-top serum BD Vacutainer tube. Plasma was separated by centrifugation (Heraeus Labofuge 400 series, Buckinghamshire, England) at $2400 \mathrm{~g}$ for $6 \mathrm{~min}$ within $20 \mathrm{~min}$ of sample collection. Following separation, plasma samples were sent to clinical laboratories for analytical chemistries (see below). Serum was separated by centrifugation (VWR International, Clinical 50 Centrifuge) at $1100 \mathrm{~g}$ for $20 \mathrm{~min}$ within 20 min of sample collection and after coagulation. Serum samples were immediately stored at $-80^{\circ} \mathrm{C}$ (Revco Freezer, GC Laboratory Equipment, Asheville, NC, USA) until the day of $25(\mathrm{OH}) \mathrm{D}$ and cytokine concentration analyses (see below).

\section{Serum 25(OH)D concentrations}

Serum $25(\mathrm{OH}) \mathrm{D}$ concentrations $(\mathrm{ng} / \mathrm{ml})$ were measured at USANA Health Sciences, Inc. (Salt Lake City, UT
USA) using a modified Bligh-Dyer technique for extraction [40] and a scaled-down and modified method as previously described [41]. Briefly, $100 \mu \mathrm{l}$ of serum was added to $400 \mu \mathrm{L}$ of a $2: 1$ methanol:chloroform solution containing dueterated $25(\mathrm{OH}) \mathrm{D}_{3}$ as an internal standard (10 ng/ $\mathrm{mL}$ in the stock solution; $40 \mathrm{ng} / \mathrm{mL}$ final concentration) in a $2 \mathrm{~mL}$ centrifuge tube. Samples were immediately vortexed and allowed to sit on ice for $10 \mathrm{~min}$. Samples were then spun at $15,000 \mathrm{~g}$ for $5 \mathrm{~min}$ and the supernatant transferred to a new $2 \mathrm{~mL}$ centrifuge tube containing 500 $\mu \mathrm{L}$ chloroform. Samples were vortexed and allowed to stand for $5 \mathrm{~min}$. To achieve phase separation, $750 \mu \mathrm{L}$ of $\mathrm{ddH}_{2} \mathrm{O}$ was added, vortexed, and centrifuged for $2 \mathrm{~min}$ at $15,000 \mathrm{~g}$. The aqueous phase (top), and any debris between the two phases, was removed and discarded. The remaining organic phase was dried down to completeness in a centrifugal vacuum concentrator for $18 \mathrm{~min}$ at $45^{\circ} \mathrm{C}$ under negative pressure. The pellet was then resuspended in $100 \mu \mathrm{L}$ of methanol and added to high performance-liquid chromatography (HPLC) vials.

Analytes were separated by injecting $10 \mu \mathrm{L}$ into an Agilent HPLC (series 6410, Model G6410B, Santa Clara, CA USA) and a Phenomenex Inertsil 3 micron, $150 \times 4.60$ $\mathrm{mm}$ column. Method conditions were: $0-8 \mathrm{~min}, 90 \%$ $\mathrm{MeOH} / 10 \%$ (0.03\% formic acid in water); $8-15 \mathrm{~min}, 30 \%$ $\mathrm{MeOH} / 70 \%$ 2-propanol; 15-20 min, 90\% $\mathrm{MeOH} / 10 \%$ ( $0.03 \%$ formic acid in water). $25(\mathrm{OH}) \mathrm{D}_{2}$ and $25(\mathrm{OH}) \mathrm{D}_{3}$ were detected on an Agilent tandem mass spectrometer (Series 6410, Model G6410B, Sant clara CA USA) using atmospheric pressure chemical ionization (APCI) detection $\left(350^{\circ} \mathrm{C}\right.$ gas temperature, $400^{\circ} \mathrm{C}$ vaporizer). The $25(\mathrm{OH}) \mathrm{D}_{3}$, dueterated $25(\mathrm{OH}) \mathrm{D}_{3}$ and $25(\mathrm{OH}) \mathrm{D}_{2}$ precursor ions were 383.3, 386.3 and 395.4, respectively. The $25(\mathrm{OH}) \mathrm{D}_{3}$, dueterated $25(\mathrm{OH}) \mathrm{D}_{3}$ and $25(\mathrm{OH}) \mathrm{D}_{2}$ productions were 365.3, 368.3 and 208.9, respectively. Serum 25 $(\mathrm{OH}) \mathrm{D}_{2}$ and $25(\mathrm{OH}) \mathrm{D}_{3}$ concentrations were determined relative to authentic standards and corrected for recovery of the $25(\mathrm{OH}) \mathrm{D}_{3}$ internal standard. The detection limit was determined to be $<1 \mathrm{ng} / \mathrm{ml}$ for all analytes. The sum of $25(\mathrm{OH}) \mathrm{D}_{2}$ and $25(\mathrm{OH}) \mathrm{D}_{3}$ concentrations was used as the $25(\mathrm{OH}) \mathrm{D}$ total concentration. However, since serum $25(\mathrm{OH}) \mathrm{D}_{2}$ was not detected in any subjects, serum 25 $(\mathrm{OH}) \mathrm{D}$ total concentrations are referred to as serum 25 $(\mathrm{OH}) \mathrm{D}$ concentrations hereafter.

\section{Cytokines}

A multiplex microsphere-bead array was used to measure a number of circulating inflammatory cytokines $(\mathrm{pg} / \mathrm{ml})$ as described previously [42,43]. Briefly, IFN- $\gamma$, IL-5 and IL-10 were quantitated using a multiplexed sandwich capture assay developed in the ARUP Institute for Clinical and Experimental Pathology (University of Utah, Salt Lake City, UT, USA) using the Luminex Multi-Analyte Profiling system (Luminex, Austin, TX, USA) [42]. 
We have reported the procedural precision of this multiplex-cytokine bead assay previously $[42,43]$. In brief, using independent control samples of low, medium, and high concentrations the coefficient of variation was calculated on 5 replicates. The intra-assay coefficient of variation was predominantly less than $10 \%$. The inter-assay coefficient of variation was predominantly less than 15\% for the medium and high control samples and up to $\sim 30 \%$ for the low control sample $[42,43]$.

\section{Clinical chemistries}

Plasma parathyroid hormone (PTH; pg/ml) and calcium $(\mathrm{mg} / \mathrm{dl})$ concentration measures were performed at ARUP Laboratories (Salt Lake City, UT USA). Plasma creatinine $(\mathrm{mg} / \mathrm{dl})$ concentrations were measured at the Central Laboratory with Intermountain Healthcare (Murray, UT USA).

To assess renal function prior to and following supplementation, the estimated glomerular filtration rate (eGFR; $\mathrm{ml} / \mathrm{min} / 1.73 \mathrm{~m}^{2}$ ) was calculated by the following equation:

$$
\mathrm{eGFR}=186 \times(\text { creatinine } / 88.4)^{-1.154} \times(\text { age })^{-0.203} \times(0.742 \text { if female }) \times(1.210 \text { if black })
$$

\section{Single-leg strength testing}

Subjects with strength or power output asymmetry (i.e., > $5 \%$ difference in peak isometric or power output between legs) were excluded from participation. Leg strength from a single randomly selected leg was performed prior to (Pre) and 28-d after (Post) placebo or vitamin D supplementation. Single-leg strength testing was performed on a horizontal plyo-press (Athletic Republic, Park City, UT USA). Plyo-press output data were measured from output signals obtained from a mounted force plate (Advanced mechanical Technology, Watertown, MA USA) and displacement transducer (UniMeasure PA-50NJC, Corvallis, OR USA). All data were sampled at 200 $\mathrm{Hz}$ with a low-pass filter at $10 \mathrm{~Hz}$ using DartPower software (Athletic Republic, Park City, UT USA, version 2.0). Before every testing session, the mounted force plate was zeroed and load calibrated.

For the single-leg peak isometric force measurements, the plyo-press sled was adjusted for each subject to align the knee and hip joint flexion angles to $90^{\circ}$ with the abdominal, lower back region secured and stabilized to the plyo-press sled with a harness. The plyo-press sled position was documented and reproduced to achieve the desired knee and hip joint flexion angles at the follow-up visits. Leg selection was randomized. Subjects were verbally instructed and strongly encouraged to exert maximal force against the mounted force platform. Each subject performed three maximal single-leg isometric contractions. Each isometric contraction was $3 \mathrm{sec}$ in duration and separated by approximately $1 \mathrm{~min}$. Peak isometric force $(\mathrm{N} / \mathrm{kg})$ was defined as the highest resultant force applied during the $3 \mathrm{sec}$ test for each trial. To calculate average isometric force, peak isometric forces from the 3 trials at each visit were averaged.

Single-leg peak power output measures followed the single-leg isometric contractions and were measured on the same horizontal plyo-press with the same securing procedures described above. Starting from an extended position (full extension $=0^{\circ}$ ), subjects performed repetitive single-leg jumps (i.e., hip and knee flexion-extension cycles) as fast as possible. Subjects were instructed to jump as high as possible. Each test was $20 \mathrm{sec}$ in duration with the weight-stack resistance set at $75 \%$ of body mass. The time-aligned product of the resultant forces (N) acquired from the force platform and weight-stack velocities $(\mathrm{m} / \mathrm{s})$ data obtained from the displacement transducer were used to calculate power output and expressed relative to body mass $(\mathrm{W} / \mathrm{kg})$. Peak power output was defined as the highest power output produced during the $20 \mathrm{sec}$ test for each leg. The peak power output for each jump during the $20 \mathrm{sec}$ test were averaged to provide an average power output for each testing session in each leg.

\section{Statistical analyses}

To achieve normality, rank transformations were performed on eGFR, serum 25(OH)D changes from Pre, and serum cytokine changes from Pre. Transformations were checked for normality with a Kolmogorov-Smirnov test. Statistical significance of data were assessed with a twoway (time, treatment) analysis of variance (ANOVA) with repeated measures, followed by a Tukey's Honestly Significant Difference to test multiple pairwise comparisons. One-way ANOVA tests were performed on subject characteristics. Relationships between variables were examined with a Pearson Product Moment Correlation. All statistical analyses were performed with SysStat software (SigmaPlot 10.0, SigmaStat 3.5, Chicago, IL, USA). Statistical significance was set at a $P<0.05$. Data presented as mean (SD) unless otherwise noted.

\section{Results}

\section{Subject characteristics}

Subject characteristics were similar between groups (Table 1). For example, there was less than a $6 \%$ difference in body mass, and importantly, less than a $1 \%$ difference in BMI between vitamin D groups (i.e., 200 vs. 4000 IU; Table 1). This is a strength of the present study because it identifies similar body sizes between supplemental vitamin D groups.

\section{Baseline vitamin D status}

Upon enrollment, serum 25(OH)D concentrations were $32.2(10.0) \mathrm{ng} / \mathrm{ml}$. Prior to randomization, $13.3(n=4)$, $23.3(n=7)$ and $63.3 \%(n=19)$ of the subjects were vitamin D deficient (serum 25(OH)D $\leq 20 \mathrm{ng} / \mathrm{ml}$ ), insufficient 
Table 1 Subject characteristics

\begin{tabular}{llll}
\hline & Placebo & 200 IU & 4000 IU \\
\hline $\mathrm{n}$ (males/females) & $10(5 / 5)$ & $10(4 / 6)$ & $10(6 / 4)$ \\
\hline Age $(\mathrm{y})$ & $30.2(4.8)$ & $26.6(3.2)$ & $29.0(5.0)$ \\
\hline Height $(\mathrm{cm})$ & $167(14)$ & $169(9)$ & $173(9)$ \\
\hline Body mass $(\mathrm{kg})$ & $72.5(17.2)$ & $69.4(17.2)$ & $73.3(15.3)$ \\
\hline Body mass index $\left(\mathrm{kg} / \mathrm{m}^{2}\right)$ & $25.5(3.0)$ & $24.0(4.1)$ & $24.2(3.6)$
\end{tabular}

Data presented as mean (SD) unless otherwise noted

Twenty-nine subjects were Caucasian; one subject was African American (placebo group)

(serum 25(OH)D 21-29 $\mathrm{ng} / \mathrm{ml}$ ) or sufficient (serum 25 $(\mathrm{OH}) \mathrm{D} \geq 30 \mathrm{ng} / \mathrm{ml})$, respectively.

Following randomization, 30, 20 and $50 \%$ of the subjects in the placebo group started study participation vitamin D deficient, insufficient or sufficient, respectively. In the 200 IU group, 10\% were deficient, 20\% were insufficient and $70 \%$ were sufficient, and in the 4000 IU group, 30\% were insufficient and $70 \%$ were sufficient when starting study participation. Based on these data, starting vitamin D status was sufficient at the group level and in groups assigned to different supplemental treatments.

\section{Serum 25(OH)D concentrations}

Treatment efficacy was evaluated by measuring serum 25 $(\mathrm{OH}) \mathrm{D}$ concentrations. Serum $25(\mathrm{OH}) \mathrm{D}$ concentrations progressively and significantly $(P<0.05)$ increased in 4000 IU group and compared to those in the placebo and 200 IU groups (Figure 1). Surprisingly, supplemental vitamin $\mathrm{D}$ at $200 \mathrm{IU}$ increased serum $25(\mathrm{OH}) \mathrm{D}$ concentrations compared to those in the placebo group (Figure 1).

Since vitamin D status tended (albeit non-significantly) to be higher in the 200 IU group upon study enrollment (Figure 1), serum 25(OH)D was normalized to Pre concentrations (change from Pre). Serum 25(OH)D concentration changes were not significantly different in the placebo or 200 IU groups (Figure 2). In contrast, serum 25(OH)D concentration changes significantly $(P<0.05)$ increased in the 4000 IU group and compared to those in placebo and 200 IU groups (Figure 2). At 21-d and 28-d, serum $25(\mathrm{OH})$ $\mathrm{D}$ concentration changes were significantly $(P<0.05)$ different between the placebo and 200 IU groups (Figure 2).

Altogether, these data indicate that 200 IU of supplemental vitamin D protected against a seasonal decrease while $4000 \mathrm{IU}$ induced a rapid increase in serum 25 $(\mathrm{OH}) \mathrm{D}$ concentrations.

\section{Clinical chemistries}

Due the anticipated seasonal decrease (which could change vitamin D status from sufficient to insufficient) and the efficacy of supplemental vitamin D at 4000 IU to increase serum $25(\mathrm{OH}) \mathrm{D}$ concentrations, PTH and

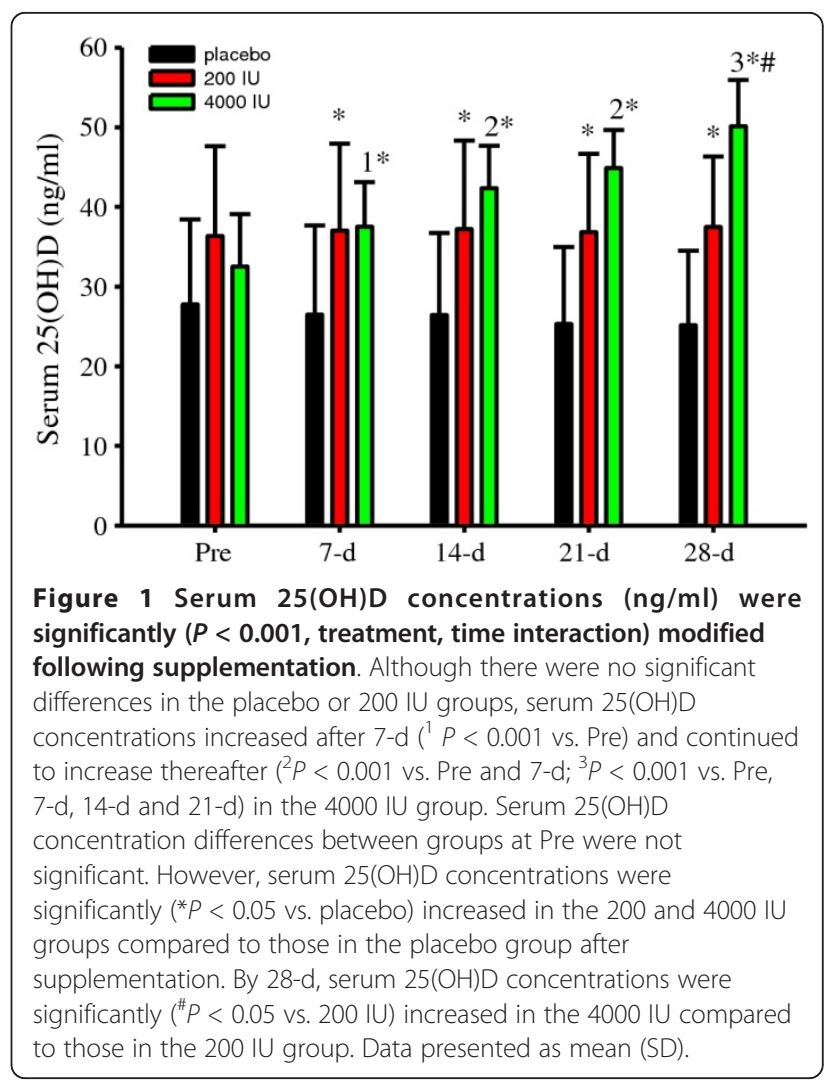

calcium were measured in each blood draw sample. PTH and calcium concentrations were not significantly different within or between groups (Table 2). Along with creatinine measures, the eGFR was calculated to

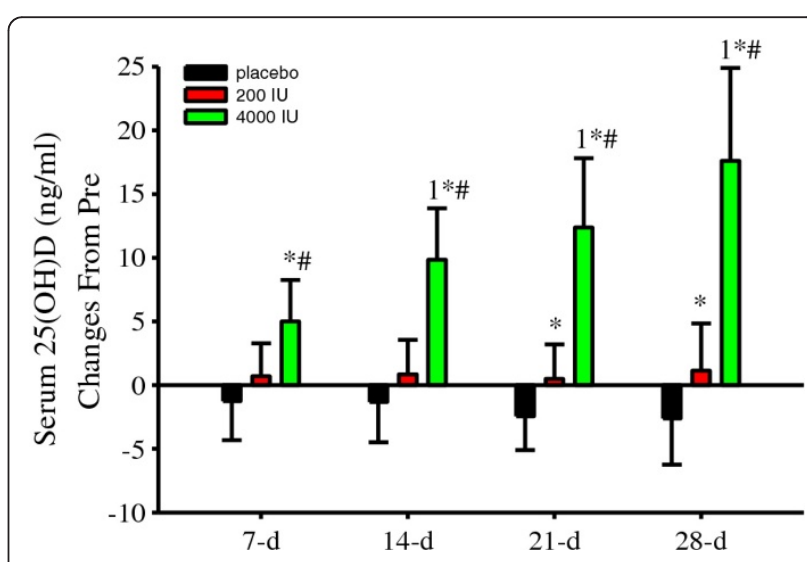

Figure 2 Serum $25(\mathrm{OH}) \mathrm{D}$ concentration $(\mathrm{ng} / \mathrm{ml})$ changes from Pre were significantly $(P<0.005$, treatment, time interaction) modulated following supplemental vitamin D. Serum 25(OH)D changes from Pre were significant $\left({ }^{1} P<0.05\right.$ vs. $\left.7-d\right)$ in the $4000 \mathrm{IU}$ group and compared to the corresponding placebo ${ }^{*} P<0.05$ vs. placebo) and $200 \mathrm{IU}\left({ }^{\#} P<0.05\right.$ vs. $\left.200 \mathrm{IU}\right)$ changes. Serum 25(OH)D concentration changes were also significantly ( ${ }^{*} P<0.05$ vs. placebo) different between the placebo and $200 \mathrm{IU}$ groups at 21-d and 28-d. Data presented as mean (SD). 
assess renal function. Creatinine and the eGFR were not significantly different within or between groups (Table 2). Thus, the seasonal decrease and supplemental vitamin Dmediated increase in serum $25(\mathrm{OH}) \mathrm{D}$ concentrations did not manifest in PTH, calcium, creatinine or eGFR alterations.

\section{Inflammatory cytokines}

Cytokine data was normalized to Pre concentrations because of variability. Following supplementation, IFN- $\gamma$ (Figure 3A) and IL-10 (Figure 3B) were not significantly different. In contrast, there was a transient and significant $(P<0.05)$ IL-5 decrease in the placebo group (Figure $3 C)$. Furthermore, IL-5 significantly $(P<0.05)$ increased in the $200 \mathrm{IU}$ group and compared to that in the placebo group at 28-d (Figure 3C). Vitamin D supplementation at 4000 IU/d did not significantly change serum IL-5 concentrations (Figure 3C). When taken in the context that our cytokine data was variable and collected in healthy adults who were monitored for only 28-d during the winter without exposure to any undue distress, these robust and unique findings illustrate that supplemental vitamin $\mathrm{D}$ maintains serum $25(\mathrm{OH}) \mathrm{D}$ and IL-5 concentrations.

Table 2 Plasma clinical chemistries

\begin{tabular}{|c|c|c|c|}
\hline & placebo & $200 \mathrm{IU}$ & $4000 \mathrm{IU}$ \\
\hline \multicolumn{4}{|c|}{ PTH $(p g / m l)$} \\
\hline Pre & $36.1(13.9)$ & $36.1(14.6)$ & $31.4(10.3)$ \\
\hline $7-d$ & $40.7(16.5)$ & $35.8(16.4)$ & $30.8(11.4)$ \\
\hline $14-d$ & $38.5(11.0)$ & $31.7(13.1)$ & $30.3(7.9)$ \\
\hline $21-d$ & $35.0(13.5)$ & $31.1(11.0)$ & $25.9(8.3)$ \\
\hline $28-d$ & $35.5(12.6)$ & $33.0(17.9)$ & $32.1(11.4)$ \\
\hline \multicolumn{4}{|c|}{ calcium (mg/dl) } \\
\hline Pre & $9.22(0.27)$ & $9.36(0.26)$ & $9.32(0.22)$ \\
\hline $7-d$ & $9.06(0.16)$ & $9.21(0.38)$ & $9.38(0.26)$ \\
\hline $14-d$ & $9.15(0.24)$ & $9.22(0.27)$ & $9.41(0.21)$ \\
\hline $21-d$ & $9.09(0.31)$ & $9.38(0.29)$ & $9.30(0.28)$ \\
\hline $28-d$ & $9.16(0.24)$ & $9.39(0.35)$ & $9.35(0.23)$ \\
\hline \multicolumn{4}{|c|}{ creatinine (mg/dl) } \\
\hline Pre & $0.93(0.08)$ & $0.91(0.14)$ & $0.98(0.17)$ \\
\hline $7-d$ & $0.92(0.08)$ & $0.97(0.16)$ & $0.98(0.15)$ \\
\hline $14-d$ & $0.94(0.09)$ & $0.92(0.13)$ & $0.97(0.17)$ \\
\hline $21-d$ & $0.92(0.13)$ & $0.92(0.15)$ & $0.98(0.15)$ \\
\hline $28-d$ & $0.94(0.16)$ & $0.91(0.15)$ & $1.01(0.13)$ \\
\hline \multicolumn{4}{|c|}{ eGFR $\left(\mathrm{ml} / \mathrm{min} / 1.73 \mathrm{~m}^{2}\right)$} \\
\hline Pre & 90.9 (15.6) & 91.9 (12.6) & $87.7(11.3)$ \\
\hline $7-d$ & $91.1(12.3)$ & $85.5(15.0)$ & $87.5(10.2)$ \\
\hline $14-d$ & $89.1(13.0)$ & $89.7(9.2)$ & $89.5(12.5)$ \\
\hline $21-d$ & $91.6(8.0)$ & $91.0(13.2)$ & $88.0(12.5)$ \\
\hline $28-d$ & $90.2(12.1)$ & $92.1(14.3)$ & $84.7(9.3)$ \\
\hline
\end{tabular}

Data presented as mean (SD)
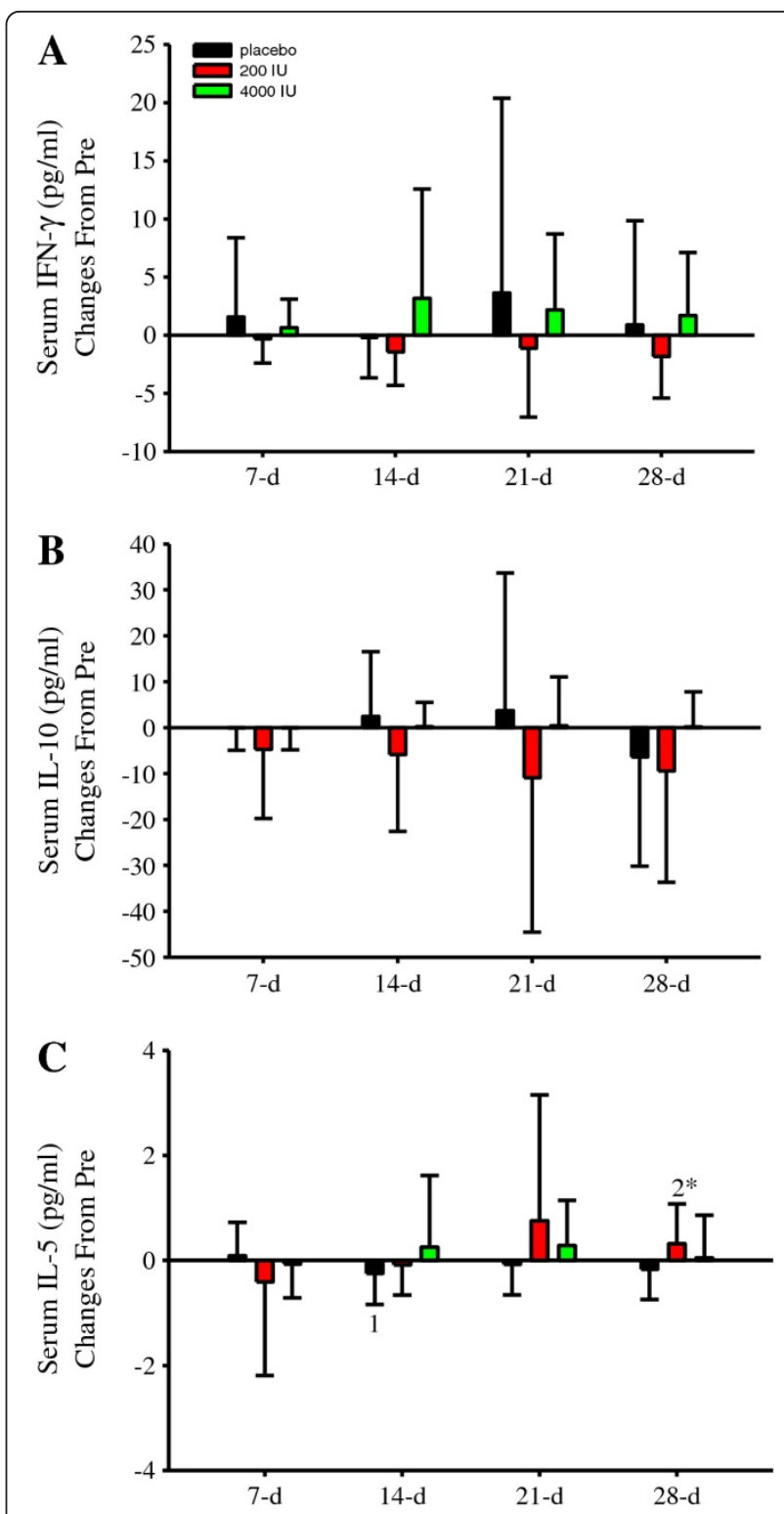

Figure 3 Serum IFN- $\gamma$, IL-10 and IL-5 concentration (pg/ml) changes from Pre. Serum IFN- $\gamma(\mathbf{A})$ and IL-10 (B) concentration changes were not significantly different within or between groups. However, IL-5 $(\mathbf{C})$ displayed a significant $(P<0.05)$ treatment, time interaction. Although no significant differences were observed within the $4000 \mathrm{IU}$ group, there was a significant and transient decrease in IL-5 at $14-d\left({ }^{1} P<0.05\right.$ vs. $\left.7-d\right)$ in the placebo and increase at $28-d\left({ }^{2} P<0.05\right.$ vs. $7-d$ and $\left.14-d\right)$ in $200 \mathrm{IU}$ group. At 28d, IL-5 changes were also significantly ( ${ }^{*} P<0.05$ ) different between the placebo and $200 \mathrm{IU}$ groups. Figure legend provided in ' $\mathbf{A}$ '. Data presented as mean (SD).

\section{Single-leg isometric forces and power outputs}

Vitamin D modulates muscular strength and power output. Herein, after 28-d of supplemental vitamin D at 200 or $4000 \mathrm{IU} / \mathrm{d}$, and compared to those in the placebo group as well, peak (Figure $4 \mathrm{~A}$ ) or average (Figure 4B) 

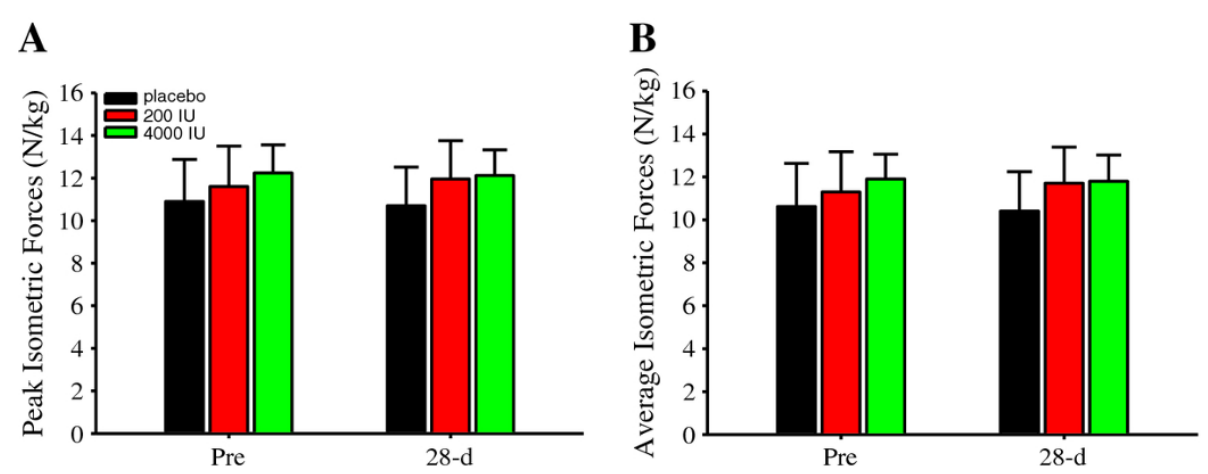

Figure 4 Single-leg isometric forces (N/kg). Single-leg peak $(\mathbf{A})$ and average $(B)$ isometric forces were not significantly different within or between groups. Figure legend provided in 'A'. Data presented as mean (SD).

isometric forces were not significantly different. Likewise, peak (Figure 5A) and average (Figure 5B) power outputs were not significantly different between supplemental groups. However, there was a significant main effect of time on peak $(P<0.05$; Figure $5 \mathrm{~A})$ and average $(P<0.05$; Figure $5 \mathrm{~B})$ power outputs, thereby indicating a learning effect.

\section{Correlations}

Although supplemental vitamin $\mathrm{D}$ did not significantly change isometric forces, peak $(r=0.27, P<0.05)$ and average $(r=0.29, P<0.05)$ isometric forces correlated with serum $25(\mathrm{OH}) \mathrm{D}$ concentrations.

\section{Discussion}

Vitamin D regulates inflammatory cytokines and skeletal muscle function, especially in isolated immune cells and various pathophysiological conditions in humans. In the present investigation, we extend those previous reports by providing several original and impactful results obtained from healthy adults during the winter. First, we provide new data identifying serum $25(\mathrm{OH}) \mathrm{D}$ and IL-5 concentration decreases. Secondly, supplemental vitamin
$\mathrm{D}$ at $200 \mathrm{IU} / \mathrm{d}$ prevented serum $25(\mathrm{OH}) \mathrm{D}$ and IL-5 concentration decreases. Third, supplemental vitamin D at $4000 \mathrm{IU} / \mathrm{d}$ induced an immediate increase in serum 25 $(\mathrm{OH}) \mathrm{D}$ concentrations without modulating circulating IL-5. Finally, despite serum 25(OH)D concentrations correlating with muscle strength, supplemental vitamin $\mathrm{D}$ did not moderate muscular strength alterations. These unique data indicate that subtle fluctuations in serum $25(\mathrm{OH}) \mathrm{D}$ concentrations modulate a $\mathrm{T}_{\mathrm{H} 2}$-type cytokine, and that muscular strength does not parallel the rapid serum $25(\mathrm{OH}) \mathrm{D}$ increase induced by a highdaily dose of supplemental vitamin D in young, reportedly active and healthy adults.

As expected, serum $25(\mathrm{OH})$ D concentrations responded disparately to different doses of supplemental vitamin D (Figures 1 and 2). Compared to serum 25(OH) D concentrations prior to supplementation, we observed a $15 \%$ increase after $7-d$, which progressively inflated by $\sim 50 \%$ after 28 -d of supplemental vitamin D at $4000 \mathrm{IU} / \mathrm{d}$. Thus, in subjects with mean serum $25(\mathrm{OH}) \mathrm{D}$ concentrations in the low- $30 \mathrm{ng} / \mathrm{ml}$ range prior to supplementation, $4000 \mathrm{IU} / \mathrm{d}$ of supplemental vitamin D induced a rapid and continuous increase in serum $25(\mathrm{OH}) \mathrm{D}$ concentrations
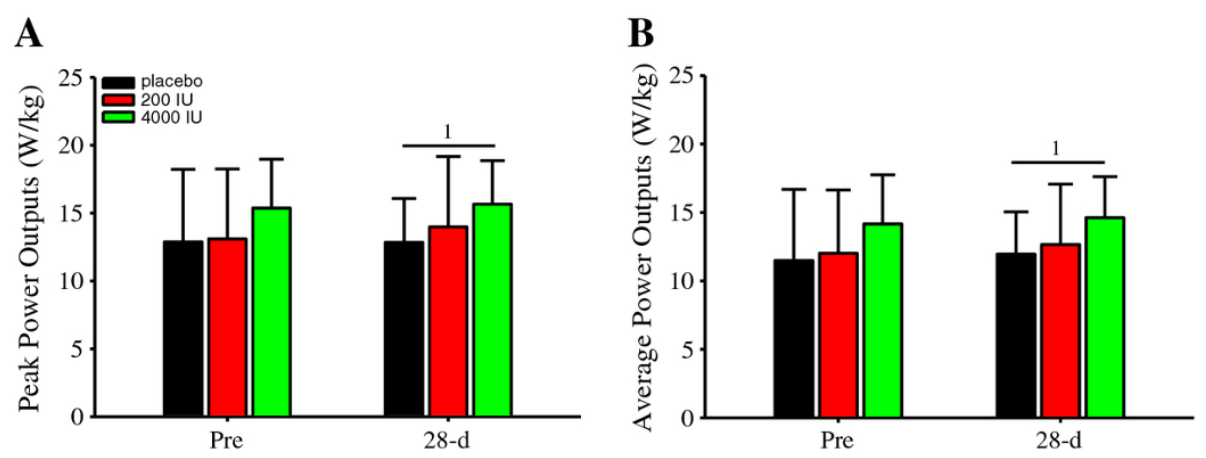

Figure 5 Single-leg power outputs $(\mathbf{W} / \mathbf{k g})$. Single-leg peak $(\mathbf{A})$ and average $(\mathbf{B})$ displayed significant (both $P<0.05)$ main effects of time. Specifically, peak $(\mathbf{A})$ and average $(\mathbf{B})$ power outputs were significantly $\left({ }^{1} P<0.05\right)$ greater at $28-\mathrm{d}$ vs. Pre. Data presented as mean (SD). 
during the winter for 28-d. Conversely, in the 200 IU group, serum $25(\mathrm{OH}) \mathrm{D}$ concentrations did not change, while serum $25(\mathrm{OH}) \mathrm{D}$ concentrations decreased in the placebo group (Figure 2; 21-d and 28-d). These are important findings because they establish consistency with previous studies that identify a decrease in serum $25(\mathrm{OH}) \mathrm{D}$ concentrations during the winter $[1,38]$. Moreover, our results indicate that at our geographical location, $200 \mathrm{IU} / \mathrm{d}$ of supplemental vitamin D plus daily dietary intake of vitamin D is adequate to maintain serum $25(\mathrm{OH}) \mathrm{D}$ concentrations and vitamin $\mathrm{D}$ sufficiency during the winter, at least in adult non-smokers and during 28-d. However, our data obtained at $200 \mathrm{IU} / \mathrm{d}$ of supplemental vitamin D dispute previous findings. Specifically, Barnes et al. [38] recently demonstrated that $200 \mathrm{IU}$ of daily vitamin D supplementation was ineffective at maintaining serum $25(\mathrm{OH}) \mathrm{D}$ concentrations during winter [38]. The more Northern geographical latitudes $\left(51^{\circ}\right.$ and $\left.55^{\circ} \mathrm{N}\right)$ and plausibly the longer supplementation duration (22 weeks) in the study by Barnes et al. [38] could be contributing factors for the discrepancy in maintaining serum $25(\mathrm{OH}) \mathrm{D}$ concentration between studies that were conducted at the same reported supplemental dose of vitamin D. This interpretation would further suggest the dose of supplemental vitamin D (plus dietary intake) required to maintain a given serum $25(\mathrm{OH}) \mathrm{D}$ concentration increases with increasing Northern latitudes during the winter. Another explanation for the discrepancy between Barnes et al. [38] and those herein could be differences in dietary vitamin $\mathrm{D}$ intake. Unfortunately, neither Barnes et al. [38] nor do we report vitamin D intake from dietary sources. Future studies are encouraged include dietary sources (and sun exposure) of vitamin D when investigating serum 25(OH)D concentrations at daily doses of supplemental vitamin $\mathrm{D}$ that are easily achievable through dietary sources. Finally, it is probable that subjects randomized to the 200 IU group had a lower percentage of body fat compared to those by Barnes et al. [38]. This could potentially lower the physiological needs of vitamin D in the 200 IU group due to less sequestering to adipose tissue. We speculate that the good vitamin D status reflected by our subjects prior to supplementation is indicative of sun exposure during the preceding summer and fall and daily dietary habits that include vitamin $\mathrm{D}$, such as the consumption of oily fish and vitamin D fortified food sources.

A novelty of the present investigation was the IL-5 results obtained with and without supplemental vitamin $\mathrm{D}$ (Figure 3C). In the placebo group, there was a transient IL-5 decrease, while in contrast, IL-5 increased in the 200 IU and remained unchanged in the 4000 IU group. Due to the small sample and effect sizes, it is plausible that $200 \mathrm{IU}$ of supplemental vitamin D maintained as opposed to increased IL-5. This premise is logically harmonious with the data obtained in the 4000 IU group, which in sum suggests that supplemental vitamin D maintains serum $25(\mathrm{OH}) \mathrm{D}$ and IL-5 concentrations during the winter. However, consistent with our increase in the $200 \mathrm{IU}$ group, Qi et al. [44] demonstrated that vitamin D (i.e., $1,25(\mathrm{OH}) \mathrm{D})$ pre-treatment in rats injected-intraperitoneally with lipopolysaccharide (LPS) increased IL-5 gene expression in the spleen [44]. Similarly, IL-5 production increased in $\mathrm{CD}^{+}$cells obtained from mice when incubated in $1,25(\mathrm{OH}) \mathrm{D}$ and stimulated with IL-2, phorbol myristate acetate (PMA) and ionomycin [45]. These results indicate that the active metabolite form of vitamin D increases IL-5. However, results vary. In an experimental mice model of pulmonary eosinophilic inflammation, subcutaneous 1,25(OH)D injections abrogated IL-5 production in bronchoalveolar lavage fluid [46]. Furthermore, when stimulated with PMA and ionomycin in the presence of $1,25(\mathrm{OH}) \mathrm{D}, \mathrm{IL}-5$ production decreased in $\mathrm{T}_{\mathrm{H} 0^{-}}$-cells and remained unchanged in $\mathrm{T}_{\mathrm{H}^{1}}$ and $\mathrm{T}_{\mathrm{H} 2}$-cells [47]. Regarding no change in IL-5, Yusupov et al. [48] demonstrated that vitamin $\mathrm{D}$ (cholecalciferol) supplementation at $2000 \mathrm{IU} / \mathrm{d}$ for 3 months was ineffective at altering circulating IL-5 concentrations in young, healthy adults. Thus, these latter studies potentially conflict with our results at $200 \mathrm{IU}$ but are in agreement with those reported herein at $4000 \mathrm{IU}$. Collectively, these findings highlight that the cytokine-modulating property of vitamin D could be physiologically dependent on the supplemental dose (and/or environmental factors and dietary intake), the immunological challenge (or lack thereof), experimental model (i.e., humans, rodents, or cell), duration of vitamin D treatment, the timing of data collection, and importantly, the form of vitamin D studied.

Regarding the form of vitamin $\mathrm{D}$, most studies have investigated the influence of $1,25(\mathrm{OH}) \mathrm{D}$ on inflammatory cytokines in vitro, which makes it is difficult to equate or interpret results relative to supplemental D or serum 25(OH)D concentration studies in humans that do not report 1,25(OH)D. Recently, Zhang et al. [49] demonstrated that $15 \mathrm{ng} / \mathrm{ml}$ of serum $25(\mathrm{OH}) \mathrm{D}$ was ineffective at suppressing LPS-induced cytokine (i.e., IL- 6 and TNF- $\alpha$ ) production in human monocytes studied in vitro. In contrast, $30 \mathrm{ng} / \mathrm{ml}$ of serum 25(OH)D significantly inhibited cytokine production and was comparable to that shown at $0.04 \mathrm{ng} / \mathrm{ml}$ of $1,25(\mathrm{OH}) \mathrm{D}$ [49]. These paramount findings indicate that serum $25(\mathrm{OH}) \mathrm{D}$ concentration, and importantly a specific circulating concentration (i.e., $\geq 30 \mathrm{ng} /$ $\mathrm{ml}$ ), is of physiological relevance regarding the anti-inflammatory property of vitamin $\mathrm{D}$ because its availability in the circulation influences the local tissue production of 1,25(OH)D [49].

Vitamin D receptors are located on T-cells and mast cells $[50,51]$, and along with eosinophils, are sources of IL-5 [52]. IL-5 is essential for promoting eosinophil growth, differentiation, survival and activation, and is 
often expressed with other $\mathrm{T}_{\mathrm{H} 2}$-type cytokines, such as IL-4 and IL-13 [53,54]. GATA-3 is a transcription factor that promotes IL-5 gene expression and promoter-transactivation in $\mathrm{T}_{\mathrm{H} 2}$-cells $[48,55]$. In $\mathrm{CD}^{+}$cells derived from mice, GATA-3 message expression increased when incubated with $1,25(\mathrm{OH}) \mathrm{D}$ [56]. In an experimental mouse model of allergic induced-asthma, 1,25(OH)D up-regulated the message expression of GATA-3 [57]. Thus, we speculate that maintaining serum $25(\mathrm{OH}) \mathrm{D}$ concentrations is necessary to sustain substrate availability for the conversion to $1,25(\mathrm{OH}) \mathrm{D}$, which subsequently modulates GATA-3 expression and prevents IL-5 decreases. With that said, it is unclear why IL- 5 did not increase in the 4000 IU group, unless there was a transient increase (or decrease) that was not detected with the timing of our blood sampling procedures.

Evidence indicates that several types of hyper-eosinophilic syndromes are mediated by IL-5 [58]. In patients with hyper-eosinophic syndrome, an anti-IL-5 monoclonal antibody (i.e., mepolizumab) spared corticosteroid use [59], which is of clinical importance since long-term corticosteroid use is associated with adverse events. Anti-IL-5 treatment also reduced the disposition of extracellular matrix proteins in bronchial biopsies obtained from atopic asthmatic patients [60], suggesting that neutralizing IL-5 minimizes the repair process following airway injury and eosinophilia. However, the increase in IL- 5 could be beneficial. In addition to increasing eosinophils, IL-5 enhances immunoglobulin A (IgA) production [61,62], which protects against a variety of viruses and bacterial infections [for review see [55]]. Recently, Halliday et al. [63] found that serum 25(OH)D concentrations inversely correlated with frequency of illness in collegiate athletes. Perhaps, maintaining or increasing IL-5, as observed in our supplemental vitamin D groups (Figure $3 \mathrm{C}$ ) who also maintained or increased as opposed to decreased serum 25(OH)D concentrations (Figure 2), could be beneficial by inducing IgA and the resistance against infectious challenge, such as the influenza virus [64]. Clearly, this premise warrants additional research.

In contrast to our hypothesis, supplemental vitamin $\mathrm{D}$ did not increase muscular strength (Figure $4 \mathrm{~A}$ and $4 \mathrm{~B}$ ) or power (Figure $5 \mathrm{~A}$ and $5 \mathrm{~B}$ ) despite serum $25(\mathrm{OH}) \mathrm{D}$ concentrations increasing by $\sim 50 \%$ in the 4000 IU group (Figure 1). This finding extends previous reports [65-67] suggesting that supplemental vitamin D does not improve muscular strength. However, previous reports, and including the results here, are not consistent with the majority of the data. There could be several reasons for the inconsistencies. First, vitamin D insufficiency or deficiency results in muscular weakness $[7,8]$. Compromised muscle strength correlated with serum $25(\mathrm{OH})$ concentrations in vitamin D deficient adolescent girls [7,9]. In vitamin D deficient elderly and stroke and osteomalacia patients, supplemental vitamin D improved muscle strength concurrently with serum $25(\mathrm{OH}) \mathrm{D}$ concentrations $[15,16$, $18,68]$. Furthermore, increasing serum $25(\mathrm{OH}) \mathrm{D}$ concentrations from $\sim 9$ to $16 \mathrm{ng} / \mathrm{ml}$ improved muscle strength and function; further but less pronounced strength and function improvements occurred from $\sim 16$ to $38 \mathrm{ng} / \mathrm{ml}$ in elderly [11], thereby indicating a diminished return in muscle strength with increasing serum $25(\mathrm{OH}) \mathrm{D}$ concentrations. In the present investigation, serum $25(\mathrm{OH}) \mathrm{D}$ concentrations were $\approx 32 \mathrm{ng} / \mathrm{ml}$ for all subjects prior to supplementing (Figure 1), and therefore, subjects were vitamin D sufficient prior to supplementing. Evidence supporting vitamin D sufficiency is also provided by the PTH and calcium concentrations (Table 2), which were within normal clinical reference ranges prior to and following supplementation and despite $25(\mathrm{OH}) \mathrm{D}$ decreases in the placebo group. Based on the existing literature and the data presented here, individuals with vitamin D insufficiency or deficiency could be more prone to muscular strength improvements with increasing serum $25(\mathrm{OH}) \mathrm{D}$ concentrations than those who are already vitamin D sufficient $[68,69]$. This theory would explain why muscle strength did not improve despite an increase in serum 25 $(\mathrm{OH}) \mathrm{D}$ concentrations following vitamin D supplementation at $4000 \mathrm{IU} / \mathrm{d}$ in subjects who were already vitamin D sufficient.

Another probable explanation for the inconsistencies in the literature is that there are few prospective, randomized studies investigating the influence of supplemental vitamin D on serum $25(\mathrm{OH}) \mathrm{D}$ concentrations and muscular strength. The majority of the evidence identifying the beneficial influence of vitamin D on muscular strength or physical performance is correlative $[9,11,12,14,69]$ or between groups demarcated on circulating $25(\mathrm{OH}) \mathrm{D}$ concentrations $[13,19]$. From these data, authors have concluded that increasing circulating $25(\mathrm{OH}) \mathrm{D}$ concentrations improves muscular strength or physical performance. Finally, our study was conducted in young adults (men and women). Studies identifying the positive influence of supplemental vitamin D on muscular-based outcomes have been conducted in elderly $[10,15]$, in patients with diverse diseases or illnesses [16-18] or in experimental animals $[70,71]$. It is plausible that healthy lifestyles in young adults mask the influence of supplemental vitamin D on muscular strength [72]. Although few arguments exist refuting the influence of vitamin D on muscular strength, future randomized trials incorporating various vitamin $\mathrm{D}$ dosing regimens that increase serum $25(\mathrm{OH}) \mathrm{D}$ concentrations differentially are required to confirm causation in young adults.

Study limitations include: first, a rather short-intervention phase. Future studies are encouraged to conduct longer durations of supplemental interventions when examining the influence of vitamin $\mathrm{D}$ on inflammatory 
cytokines and muscular strength. Second, the level of physical activity was not stringently examined. Recording activities and activity intensities and volumes performed during the preceding seasons both indoor and outdoor is recommended. Third, this study consisted of thirty subjects total ( $n=10$ /group). Future studies investigating the influence of different doses of supplemental vitamin $\mathrm{D}$ on inflammatory cytokines and muscle strength are encouraged to include a larger sample size. Fourth, our data collection was limited to weekly blood draws and emerging evidence is suggesting that the cytokine modulating property of vitamin D could be time sensitive [34]. Thus, future studies should consider the temporal cytokine response mediated by vitamin D, especially at higher doses of supplemental vitamin $\mathrm{D}$ that increase serum $25(\mathrm{OH}) \mathrm{D}$ concentrations rapidly. Next, there was variability across time in the cytokine data. To account for this variability statistically, we performed a rank transformation to achieve normality and equal variance. Finally, serum $25(\mathrm{OH}) \mathrm{D}$, inflammatory cytokines and muscular strength might respond differently in diverse populations or conditions, such as in obese, smokers, elderly or critically ill. Thus, extrapolating the present findings to other populations is not recommended.

In summary, low and high doses of supplemental vitamin D prevented serum $25(\mathrm{OH}) \mathrm{D}$ and IL-5 decreases in vitamin $\mathrm{D}$ sufficient adults during the winter. These impactful findings defy current belief by suggesting that a low dose of supplemental vitamin D (plus dietary intake) that is easily attainable through dietary sources maintains serum 25(OH)D and IL-5 concentrations.

Additionally, despite concentrations correlating with muscle strength, our shocking data reveal that muscular strength does not parallel the increase in serum $25(\mathrm{OH})$ $\mathrm{D}$ concentrations induced by supplemental vitamin $\mathrm{D}$ at $4000 \mathrm{IU} / \mathrm{d}$. We conclude that maintaining serum $25(\mathrm{OH})$ $\mathrm{D}$ concentration during the winter prevents a $\mathrm{T}_{\mathrm{H} 2}$-type cytokine decrease, which could be influential in protecting against viral and bacterial infections; and apparently in reportedly healthy and vitamin D sufficient adults, that a further increase in serum $25(\mathrm{OH}) \mathrm{D}$ mediated by a high dose of supplemental vitamin D does not improve muscular strength.

\footnotetext{
Abbreviations

1a-OHase: 1a-hydroxylase; 1,25(OH)D: 1,25-dihydroxyvitamin D; 25(OH)D: 25 hydroxyvitamin D; eGFR: Estimated glomerular filtration rate; IL: Interleukin; IFN: Interferon; PTH: Parathyroid hormone; $\mathrm{T}_{\mathrm{H} 1}$ : T helper $1 ; \mathrm{T}_{\mathrm{H} 2}: \mathrm{T}$ helper 2.

\section{Acknowledgements}

We would like to thank all the subjects that participated in this study. Supplements were generous gifts from USANA Health Sciences, Inc. (Salt Lake City, UT, USA). USANA Health Sciences, Inc. provided certificate of analyses for the vitamin D (cholecalciferol) and matching-placebo supplements. This study was funded in part the Deseret Foundation
}

(Intermountain Healthcare, Salt Lake City, UT USA) and by the ARUP Institute for Clinical and Experimental Pathology (Salt Lake City, UT USA).

\section{Author details}

${ }^{1}$ The Orthopedic Specialty Hospital, Murray, UT, 84107, USA. ${ }^{2}$ ARUP Laboratories, Institute for Clinical and Experimental Pathology, Salt Lake City, UT, 84108, USA. ${ }^{3}$ Department of Pathology, University of Utah, Salt Lake City, UT, 84132, USA. ${ }^{4}$ USANA Health Sciences, Inc., Salt Lake City, UT, 84120, USA. ${ }^{5}$ Hyperbaric Medicine, Intermountain Medical Center, Murray, UT, 84107, USA. ${ }^{6}$ LDS Hospital, Salt Lake City, UT, 84143, USA. ${ }^{7}$ University of Utah, School of Medicine, Salt Lake City, UT, 84132, USA. ${ }^{8}$ The Orthopedic Specialty Hospital, 5848 S. Fashion Blvd., Murray, UT, 84107, USA.

\section{Authors' contributions}

TB contributed to the study conception and experimental design, acquisition of data, analysis and interpretation of data, and first draft of the manuscript. TBM carried out the cytokine analysis, BMD, EDS and AD carried out the vitamin D metabolite measurements, VTH performed the single-leg strength analyses. HRH, CRK, BMD and LKW made significant contributions to the critical revision and intellectual content of this manuscript. All authors approved the final manuscript version.

\section{Competing interests}

The authors declare that they have no competing interests.

Received: 5 December 2011 Accepted: 9 March 2012

Published: 9 March 2012

\section{References}

1. Webb AR, Kline L, Holick MF: Influence of season and latitude on the cutaneous synthesis of vitamin D3: exposure to winter sunlight in Boston and Edmonton will not promote vitamin D3 synthesis in human skin. J Clin Endocrinol Metab 1988, 67:373-378.

2. Holick MF: Vitamin D deficiency. N Engl J Med 2007, 357:266-281.

3. Barger-Lux MJ, Heaney RP, Dowell S, Chen TC, Holick MF: Vitamin D and its major metabolites: serum levels after graded oral dosing in healthy men. Osteoporos Int 1998, 8:222-230.

4. Vieth R, Chan PC, MacFarlane GD: Efficacy and safety of vitamin D3 intake exceeding the lowest observed adverse effect level. Am J Clin Nutr 2001, 73:288-294.

5. Heaney RP, Davies KM, Chen TC, Holick MF, Barger-Lux MJ: Human serum 25-hydroxycholecalciferol response to extended oral dosing with cholecalciferol. Am J Clin Nutr 2003, 77:204-210.

6. Vieth $\mathrm{R}$, Carter $\mathrm{G}$ : Difficulties with vitamin $\mathrm{D}$ nutrition research: objective targets of adequacy, and assays for 25-hydroxyvitamin D. Eur J Clin Nutr 2001, 55:221-222.

7. Foo LH, Zhang Q, Zhu K, Ma G, Hu X, Greenfield H, et al: Low vitamin D status has an adverse influence on bone mass, bone turnover, and muscle strength in Chinese adolescent girls. J Nutr 2009, 139:1002-1007.

8. Wicherts IS, van Schoor NM, Boeke AJ, Visser M, Deeg DJ, Smit J, et al: Vitamin $D$ status predicts physical performance and its decline in older persons. J Clin Endocrinol Metab 2007, 92:2058-2065.

9. Ward KA, Das G, Berry JL, Roberts SA, Rawer R, Adams JE, et al: Vitamin D status and muscle function in post-menarchal adolescent girls. J Clin Endocrinol Metab 2009, 94:559-563.

10. Janssen HC, Samson MM, Verhaar HJ: Muscle strength and mobility in vitamin D-insufficient female geriatric patients: a randomized controlled trial on vitamin D and calcium supplementation. Aging Clin Exp Res 2010, 22:78-84.

11. Bischoff-Ferrari HA, Dietrich T, Orav EJ, Hu FB, Zhang Y, Karlson EW, et al: Higher 25-hydroxyvitamin D concentrations are associated with better lower-extremity function in both active and inactive persons aged $>$ or $=60$ y. Am J Clin Nutr 2004, 80:752-758.

12. Iannuzzi-Sucich M, Prestwood KM, Kenny AM: Prevalence of sarcopenia and predictors of skeletal muscle mass in healthy, older men and women. J Gerontol A Biol Sci Med Sci 2002, 57:M772-M777.

13. Houston DK, Cesari M, Ferrucci L, Cherubini A, Maggio D, Bartali B, et al: Association between vitamin $D$ status and physical performance: the InCHIANTI study. J Gerontol A Biol Sci Med Sci 2007, 62:440-446. 
14. Bischoff HA, Stahelin HB, Urscheler N, Ehrsam R, Vonthein R, Perrig-Chiello P, et al: Muscle strength in the elderly: its relation to vitamin D metabolites. Arch Phys Med Rehabil 1999, 80:54-58.

15. Verhaar HJ, Samson MM, Jansen PA, de Vreede PL, Manten JW, Duursma SA: Muscle strength, functional mobility and vitamin D in older women. Aging (Milano) 2000, 12:455-460.

16. Sato $Y$, Iwamoto J, Kanoko T, Satoh K: Low-dose vitamin D prevents muscular atrophy and reduces falls and hip fractures in women after stroke: a randomized controlled trial. Cerebrovasc Dis 2005, 20:187-192.

17. Floyd M, Ayyar DR, Barwick DD, Hudgson P, Weightman D: Myopathy in chronic renal failure. Q J Med 1974, 43:509-524.

18. Glerup H, Mikkelsen K, Poulsen L, Hass E, Overbeck S, Andersen H, et al: Hypovitaminosis D myopathy without biochemical signs of osteomalacic bone involvement. Calcif Tissue Int 2000, 66:419-424

19. Barker T, Martins TB, Hill HR, Kjeldsberg CR, Trawick RH, Weaver LK, et al: Low vitamin $D$ impairs strength recovery after anterior cruciate ligament surgery. J Evidence-Based Compl Altern Med 2011, 16:201-209.

20. Cher DJ, Mosmann TR: Two types of murine helper T cell clone. II. Delayed-type hypersensitivity is mediated by TH1 clones. J Immunol 1987, 138:3688-3694.

21. Stout RD, Bottomly K: Antigen-specific activation of effector macrophages by IFN-gamma producing (TH1) T cell clones. Failure of IL-4-producing (TH2) T cell clones to activate effector function in macrophages. $J$ Immunol 1989, 142:760-765.

22. Macatonia SE, Hosken NA, Litton M, Vieira P, Hsieh CS, Culpepper JA, et al: Dendritic cells produce IL-12 and direct the development of Th1 cells from naive CD4+ T cells. J Immunol 1995, 154:5071-5079.

23. Penna G, Armuchastequi S, Giarratana N, Daniel KC, Vulcano M, Sozzani S, et al: 1 Alpha,25-dihydroxyvitamin D3 selectively modulates tolerogenic properties in myeloid but not plasmacytoid dendritic cells. J Immunol 2007, 178:145-153.

24. Rigby WF, Denome S, Fanger MW: Regulation of lymphokine production and human $T$ lymphocyte activation by 1,25-dihydroxyvitamin D3. Specific inhibition at the level of messenger RNA. J Clin Invest 1987, 79:1659-1664.

25. Reichel H, Koeffler HP, Tobler A, Norman AW: 1 alpha,25-Dihydroxyvitamin D3 inhibits gamma-interferon synthesis by normal human peripheral blood lymphocytes. Proc Natl Acad Sci USA 1987, 84:3385-3389.

26. Coffman RL, Seymour BW, Lebman DA, Hiraki DD, Christiansen JA, Shrader B, et al: The role of helper T cell products in mouse B cell differentiation and isotype regulation. Immunol Rev 1988, 102:5-28

27. Boom WH, Liano D, Abbas AK: Heterogeneity of helper/inducer $T$ lymphocytes. II. Effects of interleukin 4- and interleukin 2-producing $T$ cell clones on resting B lymphocytes. J Exp Biol 1988, 167:1350-1363.

28. Killar L, MacDonald G, West J, Woods A, Bottomly K: Cloned, la-restricted T cells that do not produce interleukin 4(IL 4)/B cell stimulatory factor 1 (BSF-1) fail to help antigen-specific B cells. J Immunol 1987, 138:1674-1679.

29. Fiorentino DF, Bond MW, Mosmann TR: Two types of mouse T helper cell. IV. Th2 clones secrete a factor that inhibits cytokine production by Th1 clones. J Exp Med 1989, 170:2081-2095.

30. Moore KW, Vieira P, Fiorentino DF, Trounstine ML, Khan TA, Mosmann TR: Homology of cytokine synthesis inhibitory factor (IL-10) to the EpsteinBarr virus gene BCRFI. Science 1990, 248:1230-1234.

31. Lysandropoulos AP, Jaquiery E, Jilek S, Pantaleo G, Schluep M, Du Pasquier RA: Vitamin D has a direct immunomodulatory effect on CD8+ $T$ cells of patients with early multiple sclerosis and healthy control subjects. J Neuroimmunol 2011, 233:240-244.

32. Barrat FJ, Cua DJ, Boonstra A, Richards DF, Crain C, Savelkoul HF, et al: In vitro generation of interleukin 10-producing regulatory CD4(+) T cells is induced by immunosuppressive drugs and inhibited by $\mathrm{T}$ helper type 1 (Th1)- and Th2-inducing cytokines. J Exp Med 2002, 195:603-616.

33. Heine $G$, Niesner $U$, Chang HD, Steinmeyer A, Zugel U, Zuberbier T, et al: 1,25-dihydroxyvitamin $\mathrm{D}(3)$ promotes IL-10 production in human $\mathrm{B}$ cells. Eur J Immunol 2008, 38:2210-2218.

34. Matilainen JM, Husso T, Toropainen $S$, Seuter $S$, Turunen MP, Gynther $P$, et al: Primary effect of 1alpha,25(OH)D on IL-10 expression in monocytes is short-term down-regulation. Biochim Biophys Acta 2010, 1803:1276-1286.

35. Khoo AL, Chai LY, Koenen HJ, Sweep FC, Joosten I, Netea MG, et al: Regulation of cytokine responses by seasonality of vitamin $\mathrm{D}$ status in healthy individuals. Clin Exp Immunol 2011, 164:72-79.
36. Schleithoff SS, Zittermann A, Tenderich G, Berthold HK, Stehle P, Koerfer R: Vitamin $D$ supplementation improves cytokine profiles in patients with congestive heart failure: a double-blind, randomized, placebo-controlled trial. Am J Clin Nutr 2006, 83:754-759.

37. Jorde R, Sneve M, Torjesen PA, Figenschau Y, Goransson LG, Omdal R: No effect of supplementation with cholecalciferol on cytokines and markers of inflammation in overweight and obese subjects. Cytokine 2010, 50:175-180.

38. Barnes MS, Horigan G, Cashman KD, Hill TR, Forsythe LK, Lucey AJ, et al: Maintenance of Wintertime Vitamin D Status with Cholecalciferol Supplementation Is Not Associated with Alterations in Serum Cytokine Concentrations among Apparently Healthy Younger or Older Adults. J Nutr 2011, 141:476-481.

39. Institute of Medicine: Dietary reference intakes for calcium and vitamin D Washington, D.C.: The National Academies Press; 2010.

40. Blight $E G$, Dyer WJ: A rapid method of total lipid extraction and purification. Can J Biochem Physiol 1959, 37:911-917.

41. Jones G: Assay of vitamins D2 and D3, and 25-hydroxyvitamins D2 and D3 in human plasma by high-performance liquid chromatography. Clin Chem 1978, 24:287-298.

42. Martins TB, Pasi BM, Pickering JW, Jaskowski TD, Litwin CM, Hill HR: Determination of cytokine responses using a multiplexed fluorescent microsphere immunoassay. Am J Clin Pathol 2002, 118:346-353.

43. Martins TB, Anderson JL, Muhlestein JB, Horne BD, Carlquist JF, Roberts WL, et al: Risk factor analysis of plasma cytokines in patients with coronary artery disease by a multiplexed fluorescent immunoassay. Am J Clin Pathol 2006, 125:906-913.

44. Qi XP, Li P, Li G, Sun Z, Li JS: 1,25-dihydroxyvitamin D(3) regulates LPSinduced cytokine production and reduces mortality in rats. World $J$ Gastroenterol 2008, 14:3897-3902.

45. Dent LA, Strath M, Mellor AL, Sanderson CJ: Eosinophilia in transgenic mice expressing interleukin 5. J Exp Med 1990, 172:1425-1431.

46. Matheu V, Back O, Mondoc E, Issazadeh-Navikas S: Dual effects of vitamin D-induced alteration of $\mathrm{TH} 1 / \mathrm{TH} 2$ cytokine expression: enhancing lgE production and decreasing airway eosinophilia in murine allergic airway disease. J Allergy Clin Immunol 2003, 112:585-592.

47. Mahon BD, Wittke A, Weaver V, Cantorna MT: The targets of vitamin D depend on the differentiation and activation status of CD4 positive $T$ cells. J Cell Biochem 2003, 89:922-932.

48. Yusupov E, Li-Ng M, Pollack S, Yeh JK, Mikhail M, Aloia JF: Vitamin d and serum cytokines in a randomized clinical trial. Int J Endocrinol 2010, 2010:1-7.

49. Zhang Y, Leung DYM, Richers BN, Liu Y, Remigio LK, Riches DW, et al: Vitamin $D$ inhibits monocyte/macrophage proinflammatory cytokine production by targeting MAPK phosphatase-1. J Immunol 2012, 188, doi:10.4049/jimmunol.1102412.

50. Babina M, Krautheim M, Grutzkau A, Henz BM: Human leukemic (HMC-1) mast cells are responsive to 1alpha, 25-dihydroxyvitamin $D(3)$ : selective promotion of ICAM-3 expression and constitutive presence of vitamin D (3) receptor. Biochem Biophys Res Commun 2000, 273:1104-1110.

51. Veldman CM, Cantorna MT, DeLuca HF: Expression of 1,25dihydroxyvitamin $\mathrm{D}(3)$ receptor in the immune system. Arch Biochem Biophys 2000, 374:334-338.

52. Sanderson CJ: Interleukin-5, eosinophils, and disease. Blood 1992, 79:3101-3109.

53. Shimbara A, Christodoulopoulos P, Soussi-Gounni A, Olivenstein R Nakamura $Y$, Levitt RC, et al: IL-9 and its receptor in allergic and nonallergic lung disease: increased expression in asthma. J Allergy Clin Immunol 2000, 105:108-115.

54. Verheyen J, Bonig H, Kim YM, Banning U, Mauz-Korholz C, Kramm C, et al: Regulation of interleukin-2 induced interleukin-5 and interleukin-13 production in human peripheral blood mononuclear cells. Scand J Immunol 2000, 51:45-53.

55. Lamm ME: Interaction of antigens and antibodies at mucosal surfaces. Annu Rev Microbiol 1997, 51:311-340.

56. Boonstra A, Barrat FJ, Crain C, Heath VL, Savelkoul HF, O'Garra A: 1alpha,25Dihydroxyvitamin $\mathrm{d} 3$ has a direct effect on naive CD4(+) T cells to enhance the development of Th2 cells. J Immunol 2001, 167:4974-4980.

57. Wittke A, Weaver V, Mahon BD, August A, Cantorna MT: Vitamin D receptor-deficient mice fail to develop experimental allergic asthma. J Immunol 2004, 173:3432-3436. 
58. Schrezenmeier $\mathrm{H}$, Thome SD, Tewald F, Fleischer B, Raghavachar A: Interleukin-5 is the predominant eosinophilopoietin produced by cloned T lymphocytes in hypereosinophilic syndrome. Exp Hematol 1993, 21:358-365.

59. Rothenberg ME, Klion AD, Roufosse FE, Kahn JE, Weller PF, Simon HU, et al: Treatment of patients with the hypereosinophilic syndrome with mepolizumab. N Engl J Med 2008, 358:1215-1228.

60. Flood-Page P, Menzies-Gow A, Phipps S, Ying S, Wangoo A, Ludwig MS, et al: Anti-IL-5 treatment reduces deposition of ECM proteins in the bronchial subepithelial basement membrane of mild atopic asthmatics. $J$ Clin Invest 2003, 112:1029-1036.

61. Murray PD, McKenzie DT, Swain SL, Kagnoff MF: Interleukin 5 and interleukin 4 produced by Peyer's patch $T$ cells selectively enhance immunoglobulin A expression. J Immunol 1987, 139:2669-2674.

62. Lebman DA, Coffman RL: The effects of IL-4 and IL-5 on the IgA response by murine Peyer's patch B cell subpopulations. J Immunol 1988, 141:2050-2056.

63. Halliday TM, Peterson NJ, Thomas JJ, Kleppinger K, Hollis BW, LarsonMeyer DE: Vitamin D status relative to diet, lifestyle, injury, and illness in college athletes. Med Sci Sports Exerc 2011, 43:335-343.

64. Renegar KB, Small PA Jr: Immunoglobulin A mediation of murine nasal anti-influenza virus immunity. J Virol 1991, 65:2146-2148.

65. Ward KA, Das G, Roberts SA, Berry JL, Adams JE, Rawer R, et al: A randomized, controlled trial of vitamin $D$ supplementation upon musculosketal health in postmenarchal females. J Clin Endocrinol Metab 2010, 95:4643-4651.

66. Kenny AM, Biskup B, Robbins B, Marcella G, Burleson JA: Effects of vitamin $D$ supplementation on strength, physical function, and health perception in older, community-dwelling men. J Am Geriatr Soc 2003, 51:1762-1767.

67. Stockton KA, Mengersen K, Paratz JD, Kandiah D, Bennell KL: Effect of vitamin $D$ supplementation on muscle strength: a systematic review and meta-analysis. Osteoporos Int 2011, 22:859-871.

68. Zhu K, Austin N, Devine A, Bruce D, Prince RL: A randomized controlled trial of the effects of vitamin $d$ on muscle strength and mobility in older women with vitamin d insufficiency. J Am Geriatr Soc 2010, 58:2063-2068.

69. Gloth FM III, Smith CE, Hollis BW, Tobin JD: Functional improvement with vitamin $\mathrm{D}$ replenishment in a cohort of frail, vitamin D-deficient older people. J Am Geriatr Soc 1995, 43:1269-1271.

70. Pleasure D, Wyszynski B, Sumner A, Schotland D, Feldman B, Nugent N, et al: Skeletal muscle calcium metabolism and contractile force in vitamin D-deficient chicks. J Clin Invest 1979, 64:1157-1167.

71. Rodman JS, Baker T: Changes in the kinetics of muscle contraction in vitamin D-depleted rats. Kidney Int 1978, 13:189-193.

72. Ceglia L, Chiu GR, Harris SS, Araujo AB: Serum 25-hydroxyvitamin D concentration and physical function in adult men. Clin Endocrinol (Oxf) 2011, 74:370-376.

doi:10.1186/1743-7075-9-16

Cite this article as: Barker et al: Different doses of supplemental vitamin D maintain interleukin-5 without altering skeletal muscle strength: a randomized, double-blind, placebo-controlled study in vitamin D sufficient adults. Nutrition \& Metabolism 2012 9:16.

\section{Submit your next manuscript to BioMed Central and take full advantage of:}

- Convenient online submission

- Thorough peer review

- No space constraints or color figure charges

- Immediate publication on acceptance

- Inclusion in PubMed, CAS, Scopus and Google Scholar

- Research which is freely available for redistribution

Submit your manuscript at www.biomedcentral.com/submit
Biomed Central 